\title{
Determinants of Tax Revenues: Evidence From a Sample of Lower Middle Income Countries
}

\author{
Rachid Boukbech ${ }^{1}$, Ahmed Bousselhami ${ }^{2}$ \& Elhadj Ezzahid ${ }^{3}$ \\ ${ }^{1}$ Ph.D. student, Faculty of Legal, Economic and Social Sciences of Tangier, Research team in Economy, Finance and \\ Development (EFED), University Abdelmalek Essâadi, Morocco \\ ${ }^{2}$ Faculty of Legal, Economic and Social Sciences of Tangier, Research team in Economy, Finance and Development \\ (EFED), University Abdelmalek Essâadi, Morocco \\ ${ }^{3}$ Faculty of Legal, Economic and Social Sciences-Agdal, Laboratory of Applied Economics, University Mohammed V, \\ Rabat, Morocco \\ Correspondence: Rachid Boukbech, Ph.D. student, Faculty of Legal, Economic and Social Sciences of Tangier, Research \\ team in Economy, Finance and Development (EFED), University Abdelmalek Essâadi, Morocco.
}

Received: May 17, 2018

doi:10.11114/aef.v6i1.3280
Accepted: June 5, 2018 Available online: November 21, 2018

URL: https://doi.org/10.11114/aef.v6i1.3280

\begin{abstract}
Our goal in this paper is to explore the determinants of tax revenues in developing countries. After reviewing the main determinants discussed in economic literature, two models are estimated in a panel including 29 lower middle income countries over the period 2001-2014. The first concerns the tax capacity and the second the tax effort. The results show that per capita GDP and the value added of agriculture are significantly and positively correlated with tax revenues. The degree of openness has a positive but insignificant effect on tax revenues. The impact of population growth rate is negative but not significant. For the determinants of tax effort, the impacts of inflation and public spending are significant and positive. The relationship between the tax effort and the variables "public aid received" and "foreign debt" is significantly negative.
\end{abstract}

Keywords: tax revenues, tax capacity, tax effort, developping countries

JEL code: $\mathrm{H} 2, \mathrm{O} 1, \mathrm{O} 2$

\section{Introduction}

In developing countries, the state is challenged by the increasing needs of its citizens and by the limitedness of the resources it can mobilize. This situation is accentuated, on the one hand, by the high increase of the costs of public services, which become difficult to sustain, especially in the actual context of limitation of compulsory levies, and on the other hand, by the pressure of public opinion requesting the optimization of the use of public funds through effecient public policies. In this context, marked by the scarcity of resources and by the unlimitedness of needs, the supply of public goods requires a special focus on the mobilization of the different resources in order to implement a tax policy capable to generate the maximum financing.

Tax policy is one of the instruments by which public action impacts economic growth. Indeed, taxes are the main source of funds to finance essential services and to invest in public goods in the long run. The complexity of the tax system and the issues related to its governance in developing countries require the implementation of reforms to improve the relationship between tax administration and taxpayers in order to promote their adhesion and to integrate the evolution of social demand into the making of public policies.

The issues that face the state are manifested in its efforts to mobilize its tax capacity (denoted hereafter $\tau B$ with $B$ the tax base and $\tau$ the uniform rate of taxation) within the limit of the maximum taxable resources of taxpayers. Therefore, the interest of analyzing the different factors determining the tax revenues $(R)$. This leads us to analyze the factors that determine the tax capacity on the one hand, and those of the tax effort (hereafter denoted $\boldsymbol{e}$ ) on the other hand. For this, we use the technique of panel econometrics on a sample of 29 developing countries across the period 2001-2014. 
The paper is structured as follows. In section 2, we review the literature to clarify the conceptual framework for tax revenues $(R)$, tax capacity $(\tau B)$, and tax effort $(e)$ and the main factors influencing tax revenues. Section 3 is devoted to the specification of the models to be estimated and to present and discuss the empirical results. In section 4 we conclude.

\section{Determinants of Tax Revenues}

\subsection{Conceptual Framework}

Tax performance is determined by tax collecting degree. Several studies analysed the factors that determine tax revenues mobilization especially in developing countries.

Public levy may correspond to either total collected tax revenues $(R)$ or to the sum of tax and non-tax revenues such as the operating income and public domain revenues. When non-tax revenues are important, especially in countries with important mineral and oil endowments, it is preferale to focus on total public revenues (Brun, Chambas, \& Guerineau, 2007).

In this paper we focus on the determinants of tax revenues. In this respect, two components are distinguished in the tax revenues : the component determined by structural factors on which government has little control in the short-term (tax capacity $=\tau B$ ), and the component determined by public policy influenced by either direct or indirect government action $($ tax effort $=e)($ Brun, Chambas, \& Combes, 2006).

The concept of tax effort was introduced by Lotz and Mors (1967) to study and assess international tax ratios in countries sharing similar economic situations. They discussed variables determining tax effort $(e)$. In fact, this indicator is obtained by dividing real tax revenues $(R)$ on the country's tax capacity indicator $(\tau B)$. The latter represents the maximum level of tax revenues that a country can collect given its economic, social, institutional and demographic characteristics (Fenochietto \& Pessino, 2010).

The concept of tax effort has undergone some amendments following the work of Stostky and WoldeMariam (1997). They define tax effort "as a ratio of tax revenues to some measure of taxable capacity" (Stostky and WoldeMariam, 1997, p. 10). For these authors, "there are two main approaches normally used to make international comparisons of tax effort" (Stostky and WoldeMariam, 1997, p. 10). The first one assumes that the tax base, often GDP, "is a proper measure of taxable capacity" (Stostky and WoldeMariam, 1997, p. 10). The seconde approach "measures taxable capacity by regressing for a sample of countries the tax revenue to GDP ratio on explanatoty variables that serve a proxies for possible tax bases and other factors that might affect a country's ability to raise tax revenues...They also assume that the tax bases and other explanatory variables reflect only differences in taxable capacity and not tax effort" (Stostky and WoldeMariam, 1997, p. 10).

The study conducted, in 2011, by the West African Monetary Agency (WAMA) about the tax effort in Economic Community of West African States (ECOWAS) indicated that tax effort measures the degree of tax capacity mobilization in a country. It is a static measure of a country's tax performance at each point in time (each year for example). Tax effort is equal to the ratio of effective taxes $(\mathrm{R})$ to expected value of taxes $(\tau B)$ (AMAO, 2011). it is the ability to increase tax revenues by deploying different tax policies (Garg, Goyal, \& Pal, 2014).

Langford and Ohlenburg (2015) define tax capacity as the maximum level of collected tax which a country could reasonably achieve at a given point in time depending on the characteristics of its economy. As for tax effort, it is a proportion that measures the level of real tax revenues relative to a country's taxing capacity. Such an effort depends on the relevance of public choices and on the effectiveness of tax administration.

Brown and Martinez-Vazquez (2015) define tax effort as the ratio of real tax revenues to the potential level of tax resources that an economy offers. Tax capacity can be defined as the theoretical maximum level of tax revenues which a country could collect given the structural features of its economy.

\subsection{Determinants of Tax Revenues}

A set of structural and cyclical factors influences the level of collected tax revenues. In this paper, we will not be exhaustive in presenting all tax revenues factors. We brievely cite the main ones.

According to Kaldor (1963), tax revenues in underdeveloped countries are generally much lower than in developed countries because tax can only be paid from the surplus of income over the minimum subsistence' needs of the population. Therefore, the volume of national income that a poor country can turn into taxes to finance collective needs, without creating intolerable social tensions, is much smaller than in a rich country. The level of per capita income, which is considered an approximation of a country's degree of economic development, is positively correlated with tax revenues (Fenochietto and Pessino, 2013). Indeed, it is possible to assume that the higher the level of development of a country, the greater its capacity to raise resources (Brun et al., 2006). 
Kaldor (1963) argued that poor countries cannot entirely finance their development programs by only their own resources. Therefore, rich countries must assist these countries by providing support to finance these programs. According to the same author, this aid can only be effective if it is considered as a complement to the effort of poor countries and not as a substitute. In this regard, he argued that a larger aid flow would encourage the state to make less tax effort. However, the costs associated with the aid (instability of aid flows, procedural difficulties and various constraints, cost of the component borrowed, etc.) can have an opposite effect and push the states to intensify their tax effort. In addition, the negative impact of aid on government revenues may be accentuated or reduced by the quality of institutions. A country with initially weak institutions - therefore with a reduced capacity to collect tax revenues - would have a stronger incentive to reduce its tax effort in response to increased aid (Azam, Devarajan, \& O'Connell, 1999).

The expansive or restrictive nature of monetary and fiscal policies could influence the collection of tax revenues (Brun et al., 2007). The fiscal policy implemented in the past directly influences the determination of the contemporary tax burden. Indeed, past budget deficits translate into a high debt service to finance. This pushes the government to increase the tax burden given the mandatory nature of debt service. Similarly, a significant primary deficit in the previous years would allow to anticipate the increase of future debt burden and would therefore encourages the state to make an additional tax effort.

In addition, the influence of monetary and exchange rate policies on the tax effort is also indirect. Expansionary monetary policy tends to increase the rate of inflation. This effect is a constraint for the mobilization of tax resources since there is a gap between the date of imposition and the date of collection of taxes by the state; the real value of the collected tax revenues is eroded by inflation (Keynes-Oliveira-Tanzi effect ${ }^{1}$ ).

The quality of institutions (tax and customs administrations) directly determines the volume of tax revenues. Other features of the institutional structure of a country (justice, financial institutions, business characteristics) affect tax revenues (Brun et al., 2007).

A wide empirical literature demonstrates a correlation between tax income collection and a broad range of developmental, structural and institutional indicators. Results vary quite significantly from one study to another depending on the estimation methods and the adopted specification. Langford and Ohlenburg (2015) estimated tax capacity and tax effort using a stochastic frontier analysis model that includes 26 predictors and 3 other variables whose effect has never been tested in the tax capacity literature. The sample studied is composed of 85 non-natural resource-rich countries for the period 1985-2010. The results of the study show that corruption, law and the level of democracy play a significant role in determining the tax capacity. The level of tax income collected by low income and lower middle-income countries varies on average between $50 \%$ and $60 \%$ of their potential, compared to a $70 \%$ for high-income and upper middle-income countries.

In another paper, a similar approach was followed to analyze for 29 Indian states the determinants of tax revenues over the period 1992-2011 (Garg et al., 2014). The model used as dependent variable the ratio of tax incomes to GDP. The first category of explanatory variables includes variables used to estimate tax capacity such as economic variables, indicators of infrastructure availability and demographic variables. The second category includes variables that capture the inefficiency of tax administration: administrative and policy variables. The results of the analysis show that tax efforts differs widely from one state to another and that tax capacity is influenced not only by its tax base, but also by economic, demographic and political variables. Moreover, the transfers that the states receive from the central government influence their tax efforts. On the other hand, the coefficients on the political variables did not give conclusive results. Yet, political competition, approached by the number of seats won by each political party, within each state, has a favorable impact on the tax effort.

Eltony's (2002) paper focuses on 16 Arab countries during the period 1994-2000. He constructed a tax effort index by dividing the share of real tax income by the potential tax income. The paper aimes to analyze the different factors that influence the share of tax revenues in GDP. To do this, the main factors selected are: the share of agriculture in GDP, the share of the extractive industry in GDP, the share of the manufacturing industry in GDP, the per capita income, the share of exports and imports in GDP and the share of external debt. The author shows that tax effort indices were unstable during the period 1994-2000 despite their upward trend from 12.60\% in 1994 to $14.90 \%$ in 2000. His econometric "results suggest that the main determinants of the tax share in the GDP for the Arab countries are the per capita income, the share of agriculture in GDP, and the share of mining in GDP" (Eltony, 2002, p. 13)

\footnotetext{
${ }^{1}$ The Inflation can affect the real value of tax burden when there are significant time lags between tax assessment and tax collection. In many countries, taxes are assessed in one year but only collected the year after or even later. As a consequence, any increase in inflation in the interim would reduce tax burden. This phenomenon is what economists call the "Olivera-Tanzi effect" (MAS, 1999, p. 3).
} 
Piancastelli (2001) explored the tax effort for a panel of 75 countries during the period 1985-1995. The sample was divided into 3 groups: 31 low income countries, 19 middle income countries and 25 high income countries. The study show that per capita income, the ratio of trade to GDP, and the agriculture sector GDP share are significantly linked to tax effort. Other variables used in previous studies have been tested but have not been significant in this study. These include the share of mining in GDP and the ratio M3/GDP.

The study of Leuthold (1987) on the index of tax effort in a panel of 8 African countries during the period 1973-1981 found the existence of a significantly negative statistical relationship between the ratio of tax revenues to GDP and of per capita income. The same result is confirmed for the share of agriculture in GDP. However, the relationship is positive for the share of mining in GDP.

\section{Methodology, Results and Discussion}

\subsection{Specification of Models And Estimation Methodology}

The tax effort $(e)$ is the ratio of the level of collected tax revenues $(R)$ to the estimated potential or tax capacity $(p=\tau B)$. Formally we have:

$$
\mathrm{e}=\frac{R}{p}
$$

Where $p=\tau \times B$ ( $B$ is the tax base and $\tau$ is the tax rate). This gives:

$$
\mathrm{R}=\mathrm{e} \times \mathrm{p}=\mathrm{e} \times \tau \times \mathrm{B}
$$

Thus, the rate of growth of these variables are linked as follows:

$$
g_{R}=g_{e}+g_{p}=g_{e}+g_{\tau}+g_{B}
$$

The specification of the models to be estimated is based on the distinction made by Brun, Chambas, and Combes (2006) between the two components of tax revenues $(\mathrm{R})$ : the tax capacity $(\tau B)$ and the tax effort $(e)$. The first is determined by structural factors on which the public authorities do not act in the short term. The second component (tax effort) is determined by the decisions of public authorities. The specified models are based on the assumption of the additivity of the $\log$ of tax effort $(e)$ and the $\log$ of tax capacity $(\tau B)$ to determine the log of tax revenues in a country (Brun et al., 2007):

$$
R_{i t}=f\left(p_{i t}, e_{i t}\right)
$$

The estimation methodology consists, at first, to regress tax revenues solely on its structural determinants by a panel data model. The model chosen is specified as follows:

With:

$$
R_{i t}=\alpha_{\mathrm{i}}+\alpha_{1} g d p_{-} c a p_{i t}+\alpha_{2} a g r_{-} v a_{i t}+\alpha_{3} o d_{i t}+\alpha_{4} p o p_{-} g r w_{i t}+\mu_{i t}
$$

$\alpha_{\mathrm{i}}$ : the individual-specific effect;

$R:$ the $\log$ of Tax revenues as \% of GDP;

gdp_cap: the log of GDP per capita (constant 2010 US\$);

agr_va: the log of value added of Agriculture (\% of GDP);

$o d$ : the log of Openness degree;

pop_grw: the log of Population growth (annual \%).

The tax capacity $(\tau B)$ is measured as the predicted value of this estimated equation. That is $p=\tau B=\hat{R}_{i t}$. The tax effort is then the residual $\hat{\mu}_{i t}$ :

$$
e_{i t}=R_{i t}-p_{i t}=\hat{\mu}_{i t}
$$

The second step in the estimation procedure is to regress the tax effort on its determinants:

With:

$$
e_{i t}=\hat{\mu}_{i t}=\beta_{\mathrm{i}}+\beta_{1} \text { inf }_{i t}+\beta_{2} \exp _{i t}+\beta_{3} \text { off_ass }{ }_{i t}+\beta_{4} \text { ext_det }_{i t}+\varepsilon_{i t}
$$

$\beta_{\mathrm{i}}$ : the individual-specific effect;

$e$ : the tax effort as a residual of the tax capacity model;

inf: the log of inflation, consumer prices (annual \%);

exp: the log of Public expenditures (\% of GDP);

off_ass: the log of Net official development assistance received (constant 2013 US\$); 
ext_det: the log of External debt stocks (\% of GNI).

The data used are taken from the World Bank database for a panel of 29 lower-middle-income countries ${ }^{2}$ over the period 2001-2014. The choice of this sample is justified by the desire to have a panel of countries whose economic characteristics are similar to those of Morocco, based on the criterion of income. Missing data for lower-middle-income countries led to the reduction in the number of countries and to the shortening of the study period.

\subsection{Estimation of Tax Capacity Model}

Table 1 provides descriptive statistics of tax revenues and its structural determinants. During the period under study (2001-2014), the mean value of tax revenues in our sample is around 14\% of GDP. The minimal value of these revenues is around $0.9 \%$ obtained in Nigeria in 2004. The maximal value is recorded in 2006 in Swaziland with around 32\%. For the other variables, their mean values are $2012.845 \$$ US for GDP per capita, $17.87 \%$ for the share of Agriculture value added in GDP, $79.48 \%$ for the degree of openness and $1.55 \%$ for the population growth rate.

Table 1. Variables' Descriptive Statistics

\begin{tabular}{cccccc}
\hline & N bre & Mean & Standard deviation & Minimum & Maximum \\
\hline R & 347 & 13.94358 & 4.884043 & 0.9054617 & 32.06068 \\
gdp_cap & 406 & 2012.845 & 953.6087 & 451.9218 & 4329.252 \\
agr_va & 397 & 17.87564 & 8.10647 & 3.383118 & 48.56594 \\
od & 378 & 79.48145 & 34.94899 & 15.67526 & 193.259 \\
pop_grw & 406 & 1.554286 & 0.7986 & -0.523523 & 3.103037 \\
\hline
\end{tabular}

Source: Our results

Table 2 presents the correlation between tax revenues and its structural determinants. We notice the presence of positive correlation between tax revenues and GDP per capita as well as with the openness degree. This correlation is negative with the value added of Agriculture and with the population growth rate.

Table 2. Correlation Between Variables

\begin{tabular}{cccccc}
\hline & $\mathrm{R}$ & gdp_cap & agr_va & od & pop_grw \\
\hline $\mathrm{R}$ & 1.0000 & & & & \\
gdp_cap & 0.2926 & 1.0000 & & & \\
agr_va & -0.2910 & -0.6730 & 1.0000 & & \\
od & 0.4128 & 0.0938 & -0.1729 & 1.0000 & \\
pop_grw & -0.4165 & -0.2899 & 0.2045 & -0.2350 & 1.0000 \\
\hline
\end{tabular}

Source: Our results

The methodological approach consists to use, in a first step, the Breuch Pagen test in order to confirm the existence of specific effects in the panel under study. In a second step, and after estimating the models, we use the Haussman test with the aim to find out the privileged model to take account of the specific effects (fixed effects or random effects). The results of the estimation of the equation of tax revenues $(R)$ are shown in the following chart:

2 Armenia, Bangladesh, Bhutan, Bolivia, Cabo Verde, Cambodia, Congo, Ivory Coast, Egypt, El Salvador, Ghana, Guatemala, Honduras, India, Indonesia, Kenya, Kyrgyzstan, Moldova, Mongolia, Morocco, Nicaragua, Nigeria, Pakistan, Philippines, Sri Lanka, Swaziland, Tunisia, Vanuatu and Zambia. 
Table 3. Results of the Estimation of the Equation of Tax Revenues

\begin{tabular}{|c|c|c|c|c|}
\hline \multirow[b]{2}{*}{$\mathrm{R}$} & \multicolumn{2}{|c|}{ Estimation 1} & \multicolumn{2}{|c|}{ Estimation 2} \\
\hline & Fixed effects & Random effects & Fixed effects & Random effects \\
\hline \multirow[t]{2}{*}{ gdp_cap } & $0.4749647 * * *$ & $0.3703674 * * *$ & $0.5213165^{* * *}$ & $0.4785113 * * *$ \\
\hline & $(0.000)$ & $(0.000)$ & $(0.000)$ & $(0.000)$ \\
\hline \multirow[t]{2}{*}{ agr_va } & $0.3099306 * * *$ & $0.2470176 * * *$ & $0.2424287 * * *$ & $0.2126633 * * *$ \\
\hline & $(0.001)$ & $(0.004)$ & $(0.001)$ & $(0.003)$ \\
\hline \multirow[t]{2}{*}{ od } & 0.0598644 & $0.1169502 *$ & & \\
\hline & $(0.379)$ & $(0.058)$ & & \\
\hline \multirow[t]{2}{*}{ pop_grw } & -0.0295631 & -0.0637351 & & \\
\hline & $(0.642)$ & $(0.276)$ & & \\
\hline \multirow[t]{2}{*}{ constant } & $-1.846291 * *$ & -0.8443326 & $-2.007535^{* * *}$ & $-1.605181 * *$ \\
\hline & $(0.040)$ & $(0.308)$ & $(0.004)$ & $(0.016)$ \\
\hline \multirow[t]{2}{*}{ Hausman test } & \multicolumn{2}{|c|}{10.43} & \multicolumn{2}{|c|}{4.41} \\
\hline & \multicolumn{2}{|c|}{$(0.0338)$} & \multicolumn{2}{|c|}{$(0.1102)$} \\
\hline
\end{tabular}

Source: Our results Threshold of significance: $* 10 \%$, **5\%, and ***1\%

The Hausman test shows that the model with fixed effects is privileged on account of the probability khi2 which is less than 5\% (0,0338). According to the results, the GDP per capita affects positively and significantly tax revenues. This corroborates the ideas put forward by some authors (Kaldor, 1963). This suggests that wealthier a country is, higher the portion of its wealth devoted to taxation (Moisseron, 1999).

Similarly, the coefficient associated with the agriculture's value added is significant and positive. This positive correlation is explained by the increase in tax revenues during the years of favorable agricultural conjuncture. This may be due to the increase in the revenues related to Value Added Tax (VAT) stimulated by the increase of consumption or by the increase of VAT revenues on importation boosted by the increase of imported capital and intermediate consumption goods used by farmers or sectors serving agricultutre. Moreover, a favorable agricultural conjuncture has a positive effect on other economic activities, which has a positive impact on tax revenues (Income Tax, Corporate Tax, VAT).

Nevertheless, these results are in conflict with what is found by other researchers that documented a negative effect of agriculture's value added on tax revenues. This might be due to the exemption accorded to agricultural revenues in some countries. In addition, it is hard to apply taxes on agricultural incomes because of the fact that farming is not structured and scattered in countries that are not wealthy. Therefore, a substantial share of agriculture in the GDP must lead to weaker tax revenues (Brown \& Martinez-Vazquez, 2015).

Openness of the economy to international trade has a positive but insignificant effect on tax revenues. This correlation is explained by the fact that a raise in trade volume, generated by liberalisation, increases tax revenues (mainly import VAT) by raising the tax base (Brun et al., 2006, Fenochietto \& Pessino, 2010 \& Fenochietto \& Pessino, 2013).

The coefficient associated to "growth rate of the population" is negative and not significant. This result contradicts with other papers'findings on the issue of the determinants of tax revenues $(R)$. Neverthless, some explanations may be put forward. It may, for example, concern the problem of low level of awareness of the population in poor countries. The more a population is literate, the higher tax revenues are. Some econometric simulations show that the coefficient 
associated to literacy rate is positive. This is due to the fact that literate people are more able to get aware of the reasons behind the payment of taxes (AMAO, 2011).

In order to eliminate the effect of non-significance of the two last variables on the quality of the model, we have performed a second estimation without involving the variables "oppeness degree" and "population growth". Hausman test favors the model with random effects since the probability khi2 is bigger than à $5 \%(0,1102)$.

\subsection{Estimation of Tax Effort Model}

As noted above, the tax effort is the residue from the model estimated for the tax revenues. The interpretation of this residue is related to the average behavior of the sample retained. This means that the tax effort of each country in a given year must be compared to the average tax effort of the sample for the same period. Therefore, negative tax effort means that the country produces less tax effort than the sample mean. In other words, the policy of tax mobilization of the country in question is less effecient in comparison to the average of the panel and the inverse holds when the residue is positive (Brun et al., 2006 \& Brun et al., 2007). In this regard, we have used a new variable ( $\left.e^{\prime}\right)$ which is the tax effort of each country calculated with respect to the mean tax effort of the panel $(\bar{e})$.

As a matter of fact, the average tax effort of our sample, concerning the period 2001-2014, is 2.53 (see table 4 below). In this study, the tax effort of each country of the panel is compared to this value. That is $e_{i}^{\prime}=e_{i}-\bar{e}$. The average value of the variable $e^{\prime}$ is null. Its minimal value is -0.566 recorded in Bangladesh in 2002 whereas its maximal value is 0.466 recorded in Armenia in 2011.

$48 \%$ of countries under study ${ }^{3}$ adopt a policy of tax mobilization less efficient with regard to the average behaviour of the sample. Those countries are, therefore, called on to deploy more effort in order to better exploit their tax capacity $(\tau B)$ by implementing an appropriate policy of tax mobilization. They should reform their tax policy with a view to supporting the change of the environment. Also, the reduction of fraud must be placed high on the agenda in order to reduce the losses of tax revenues. This must be done through the fight against corruption and by raising the quality of the tax administration.

Table 4. Variables’ Descriptive Statistics

\begin{tabular}{cccccc}
\hline & N bre of observations & Mean & Standard deviation & Minimum & Maximum \\
\hline e & 345 & 2.530 & 0.193 & 1.963 & 2.996 \\
e' & 345 & 0.000 & 0.193 & -0.566 & 0.466 \\
inf & 406 & 6.96 & 5.17 & -18.10 & 32.90 \\
exp & 341 & 18.8721 & 6.269431 & 5.032467 & 38.041 \\
off_ass & 406 & $9.92 \mathrm{e}+08$ & $1.10 \mathrm{e}+09$ & $-4.42 \mathrm{e}+08$ & $1.27 \mathrm{e}+10$ \\
ext_det & 406 & 51.5271 & 35.09963 & 4.132155 & 244.9893 \\
\hline
\end{tabular}

Source: Our results

Table 5 presents the correlation between the tax effort (e) and its determinants. We notice a negative correlation between tax effort and the inflation rate, public aid, and foreign debt. The relationship between tax effort and expenditures is positive.

Table 5. Correlations between Variables

\begin{tabular}{|c|c|c|c|c|c|}
\hline & $\mathrm{e}$ & inf & $\exp$ & off_ass & ext_det \\
\hline e & 1.0000 & & & & \\
\hline inf & -0.1160 & 1.0000 & & & \\
\hline $\exp$ & 0.4132 & -0.1166 & 1.0000 & & \\
\hline off_ass & -0.2282 & 0.2288 & -0.1893 & 1.0000 & \\
\hline ext_det & -0.0398 & -0.0621 & 0.1925 & -0.2690 & 1.0000 \\
\hline
\end{tabular}

Source: Our results

\footnotetext{
3 Bangladesh, Bolivia, Cambodia, Congo, Ivory Coast, India, Kenya, Kyrgyz, Moldova, Nicaragua, Pakistan, Philippines, Vanuatu and Zambia.
} 
The results of the estimation of the equation of tax effort are shown in table 6 .

Table 6. Results of the Estimation of the Equation of Tax Effort

\begin{tabular}{ccc}
\hline e & Fixed effects & Random effects \\
\hline inf & $0.0202046 * * *$ & $0.0196799 * * *$ \\
exp & $(0.001)$ & $(0.001)$ \\
& $0.2206017 * * *$ & $(0.000)$ \\
off_ass & $(0.000)$ & $-0.01283712 * * *$ \\
ext_det & -0.0100195 & $(0.061)$ \\
& $(0.153)$ & $-0.0525649 * * *$ \\
constant & $-0.0522521 * * *$ & $(0.000)$ \\
Hausman test & $(0.000)$ & $2.320798 * * *$ \\
\end{tabular}

Source: Our results Threshold of significance: $* 10 \%, * * 5 \%$, and $* * * 1 \%$

According to the Hausman test, the model with random effects is preferred on account of the probability khi2 which is above the threshold 5\%. The results of table 6 show that the coefficients associated to inflation and to public expenditures are positive and significant. However, the sign expected for inflation is negative due to the fact that higher inflation is, weaker are tax revenues (FMI, 2011 \& Fenochietto \& Pessino, 2010). This inverse relationship may be explained, on the one hand, by the delay between the date the tax is due and its recovry date, leading to erosion of the true value of tax revenues, and on the other hand, the high rates of inflation act as a sign of bad macroeconomic environment, leading to lower investment, lower production and, thus, to lower tax revenues (AMAO, 2011). Our result concerning inflation does not corroborate the theoritically expected inverse relationship between inflation and tax revenues. This can be due to the choice of the panel and /or to the quality of data.

The result related to public expenditure ties with previous literature. This positive relationship may be attributed to the obligation to finance public expenditure by taxes. Thus, a better awareness of taxpayers as to the usefulness of public expenditures financed by their taxes to improve their quality of life may reinforce the trust in the tax system and incite to comply with it (FMI, 2011).

In addition, the raise of public resources can be achieved not only through increasing tax revenues, but also via the planning of the fiscal space by the improvement of the effectiveness of public expenditure. With unchanged resources, a raise in the effeciency of public expenditure allows the increasing of the amount of public assets offered. This may have an equivalent effect to that of the mobilization of additional resources. This enlargement of the fiscal space presents the advantage of avoiding the costs incurred following the mobilization of additional resources (ADB \& FAD, 2010).

The impact for the variable "Net official development aid received", is significantly negative. This may be explained by the existence of crowding-out effect of tax revenues affecting the attitude of states recipients of the aid and consequently undermining their tax effort (Brun et al., 2007). This variable does not receive a consensus at both theoretical and empirical level. The results of the studies dealing with the relationship between official aid and tax mobilization are unsystematic. They do not enable to conclude about the impact of the aid on tax mobilization. In this context, some of those studies suggest that there is a positive effect of the official aid received on tax effort. The existence of a complementarity relationship between official aid and tax effort explains the positive link between these two variables as aid sufficiently improves the effectiveness of public administrations in offsetting the direct negative effect related to additional funding.

The results of the estimation reveal a positive impact of external debt on tax effort. The interpretation of the relationship between external debt and tax effort is theoretically ambiguous: a high debt could be a sign of weak taxes recovery, or could spur an additional recovery of taxes (FMI, 2011). The debt burden may induce countries that are heavily indebted to mobilize more tax resources in order to allow additional resources, in particular, for the sake of offsetting the slump of tariff revenue (Attila, Chambas, \& Combes, 2011). Also, taking into consideration the mandatory nature of expenditure 
of debt service, the level of debt pushes the government to increase its tax pressure with the purpose of keeping the level of primary expenditures (expenditure excluding debt) (Brun et al., 2007). However, the poor and heavily indebted countries will show some reticence to undertake the risks of tax reform with the aim to broaden the tax base with the goal to generate more tax resources, based on the fact that a rise in compulsory levies incites the taxpayers either to cut off their activities or commit fraud. This may discourage investment as the benefits generated are to a large extent offset by increased taxes (Azimi \& Nematian, 2015).

\section{Conclusion}

Tax policy is one of the instruments by which public action impacts the mobilization of tax revenues. Nevertheless, setting up a more efficient and equitable tax system requires both political will and the mobilization of technical resources. However, structural factors, over which the public authorities have little impact in the short term, can slow down or improve the mobilization of tax revenues.

In this paper we attempt to identify the main determinants of tax revenues for lower-middle-income countries as defined by the World Bank. The annual data used are drawn from the World Bank database for a panel of 29 countries during the period 2001-2014. The econometric approach was the estimation of the tax capacity $(\tau B)$ equation first and then the tax effort $(e)$ in a second step using the panel data technique.

We find a positive and significant effect of per capita GDP and of the share of the value added of agriculture on tax revenues. The effect of the openness degree is positive but not significant. On the other hand, the population growth has a negative and insignificant effect. Regarding the tax effort, the impact of inflation and public expenses are significantly positive. The relationship between tax effort and the variables "official assistance received" and "external debt" is significantly negative.

\section{References}

Agence Monétaire de l'Afrique de l'Ouest. (2011). Effort fiscal dans les pays de la CEDEAO.

Attila, G., Chambas, G., \& Combes, J. L. (2011). Aide publique au développement et transition fiscale. Centre d'Etudes et de Recherches sur le Développement International, Document de travail de la série "Etudes et Documents", E 2009.01.

Azam, J. P., Devarajan, S., \& O’Connell, S. (1999). Aid Dependence Reconsidered. ResearchGate.

Azimi, F., \& Nematian, M. (2015). Investigating the Effect of Losses Resulting from Delay in Tax Receipt (Case Study: Bushehrand Khuzestan). Journal of Applied Environmental and Biological Sciences, ISSN: 2090-4274.

Banque Africaine de Développement, \& Fonds Africain de Développement. (2010). Evaluation du potentiel de recettes publiques: Etude économique et sectorielle. Département-pays, Région ouest 2.

Brown, L. A., \& Martinez, V. J. (2015). International Debt Forgiveness: Who Gets Picked and Its Effect On The Tax Effort Of Developing Countries. International Center for Public Policy, WP 15-04.

Brun, J. F., Chambas, G., \& Combes, J. L. (2006). Recettes publiques des pays en développement: Méthode d'évaluation. STATECO, N100.

Brun, J. F., Chambas, G., \& Guerineau, S. (2007). Aide et mobilisation fiscale dans les pays en développement. Agence Française de Développement, N 21.

Eltony, M. N. (2002). The Determinants of Tax Effort in Arab Countries. Arab Planning Institute, Kuwait.

Fenochietto, R., \& Pessino, C. (2010). Determining countries' tax effort. Fiscal Affairs Department, International Monetary Fund.

Fenochietto, R., \& Pessino, C. (2013). Understanding Countries' Tax Effort . International Monetary Fund, WP/13/244. https://doi.org/10.5089/9781484301272.001

Fonds Monétaire International. (2011). Mobilisation des recettes dans les pays en développement. Département des finances publiques.

Garg, S., Goyal, A., \& Pal, R. (2014). Why Tax Effort Falls Short of Capacity in Indian States: A Stochastic Frontier Approach. Indira Gandhi Institute of Development Research (IGIDR), WP-2014-032.

Kaldor, N. (1963). Will underdeveloped countries learn to tax? Foreign Affairs. https://doi.org/10.2307/20029626

Langford, B., \& Ohlenburg, T. (2015). Tax revenue potential and effort: An empirical investigation. Internationa Growth Center.

Leuthold, J. H. (1987). Tax Shares in Developing Economies: A Panel Study. College of Commerce and Business Administration (University of Illinois at Urbana -Champaign), Faculty working paper N. 1412. 
Lotz, J. R., \& Morss, E. R. (1967). Measuring "Tax Effort" in Developing Countries. Staff Papers, International Monetary Fund.

Moisseron, J. Y. (1999). Pression, structure fiscale et niveau de développement. In : Gastellu Jean-Marc (ed.), Moisseron Jean-Yves (ed.), Pourcet G. (ed.) Fiscalité, développement et mondialisation. Paris : Maisonneuve \& Larose, 85-106. ISBN 2-7068-1327-X.

Monetary Authority of Singapore, (1999), Inflation, Economics Explorer \#3.

Piancastelli, M. (2001). Measuring the Tax effort of developed and developing countries. Cross country panel data analysis - 1985/95. Research Institute in Applied Economy (ISSN 1415-4765).

Stostky, J. G., \& WoldeMariam, A. (1997). Tax effort in Sub-Saharan Africa. International Monetary Fund, WP/97/107.

\section{Copyrights}

Copyright for this article is retained by the author(s), with first publication rights granted to the journal.

This is an open-access article distributed under the terms and conditions of the Creative Commons Attribution license which permits unrestricted use, distribution, and reproduction in any medium, provided the original work is properly cited. 